\title{
EFEKTIVITAS PUPUK HAYATI BIOFRESH DAN PUPUK ORGANIK BOKASHI DALAM MENINGKATKAN KETAHANAN TANAMAN JAGUNG TERHADAP PENYAKIT Puccinia polysora \\ Effectiveness of Biofresh biofertilizers and Bokashi organic fertilizer in improving the resistance of corn plants against Puccinia polysora
}

Vit Neru Satrah ${ }^{a}$, Eko Aprianto Johan ${ }^{a}$, Andi Awaluddin ${ }^{b}$, Hadi Sudarmo ${ }^{c}$, Andi Khaeruni R a* Teguh Wijayanto ${ }^{\mathrm{b}}$, dan Mariadia

aprogram Studi Proteksi Tanaman, Fakultas Pertanian, Universitas Halu Oleo, Kendari, Indonesia

bProgram Studi Agroteknologi, Fakultas Pertanian, Universitas Halu Oleo, Kendari, Indonesia

'Program Studi Agribisnis, Fakultas Pertanian, Universitas Halu Oleo, Kendari, Indonesia

Doi: $10.37195 /$ jac.v2i1.90

\begin{tabular}{l} 
*KORESPONDENSI \\
\hline Telepon: +62-853-9944-2925 \\
E-mail: andikhaeruni.uho@gmail.com \\
JEJAK PENGIRIMAN \\
\hline Diterima: 8 Nov 2019 \\
Revisi Akhir: 11 Feb 2020 \\
Disetujui: 28 Mar 2020
\end{tabular}

KEYWORDS

Biofresh biofertilizers, Bokashi organic fertilizer, Maize plant, Puccinia polysora

\section{KATA KUNCI}

Pupuk hayati Biofresh, Pupuk organik bokashi, Tanaman jagung, Puccinia polysora

\begin{abstract}
This study aims to determine the effectiveness of Biofresh biofertilizers and Bokashi organic fertilizer to increase the resistance of maize plants to Puccinia leaf rust disease (Puccinia polysora). This research was conducted in Konda I village, Konda District, Konawe Selatan Regency. The experimental method was a factorial Randomized Complete Block Design consisting of 8 combinations of treatments by 3 replications so that there are 24 experimental units. The parameters observed were Disease Intensity (IP) of Puccinia leaf rust, LDBKPP, IPP, and Peroxidase Enzyme Activity Analysis. The results showed that the application of Biofresh biofertilizers and Bokashi organic compound were able to increase plant resistance to Puccinia leaf rust disease on corn plants. The lowest $L D B K P P$ value was A1B1 treatment of $220.37 \%$.days, the highest IPP was A1B1 treatment of $51.74 \%$, and the highest peroxidase enzyme activity was A1B1 treatment of 0.13 units. $\mathrm{mg}^{-1}$.
\end{abstract}

Penelitian ini bertujuan untuk mengetahui efektivitas pupuk hayati Biofresh dan bahan organik Bokashi dalam meningkatkan ketahanan tanaman jagung terhadap penyakit karat daun Puccinia (Puccinia polysora). Penelitian ini dilaksanakan di Desa Konda I, Kecamatan Konda, Kabupaten Konawe Selatan. Metode Percobaan menggunakan Rancakan Acak Kelompok (RAK) Pola Faktorial yang terdiri dari 8 kombinasi perlakuan dan ulangan 3 kali sehingga terdapat 24 unit percobaan. Parameter yang diamati adalah Intensitas Penyakit (IP) karat daun Puccinia, LDBKPP, IPP, dan Analisis Aktivitas Enzim Peroksidase. Hasil penelitian menunjukkan bahwa aplikasi pupuk hayati Biofresh dan bahan organik Bokashi mampu meningkatkan ketahanan tanaman terhadap pengakit karat daun Puccinia pada tanaman jagung. Nilai LDBKPP terendah pada perlakuan A1B1 sebesar 220,37\%.hari, IPP tertinggi pada perlakuan A1B1 sebesar $51,74 \%$ dan aktivitas enzim peroksidase tertinggi pada perlakuan A1B1 sebesar 0,13 unit.mg ${ }^{-1}$.

\section{PENDAHULUAN}

Jagung merupakan komoditas strategis dan bernilai ekonomis serta mempunyai peluang untuk dikembangkan karena kedudukannya sebagai sumber utama karbohidrat dan protein setelah beras. Bertambahnya jumlah penduduk dan 
berkembangnya industri pengolahan pangan, maka kebutuhan jagung dan penggunaannya sebagai bahan pangan akan semakin meningkat.

Berdasarkan hitungan Direktorat

Jenderal Tanaman Pangan Kementan, produksi jagung dalam 5 tahun terakhir meningkat rata-rata 12,49 persen per tahun. Itu artinya, tahun 2018 produksi jagung diperkirakan mencapai 30 juta ton pipilan kering (PK). Hal ini juga didukung oleh data luas panen per tahun yang rata-rata meningkat 11,06 persen, dan produktivitas rata-rata meningkat 1,42 persen (BPS, 2018).

Sulawesi Tenggara merupakan salah satu provinsi di Indonesia yang memiliki potensi lahan untuk pengembangan tanaman jagung. Namun saat ini produktivitas jagung di Sulawesi Tenggara masih tergolong sangat rendah dibandingkan dengan provinsi lain. Di lain pihak permintaan akan komoditas jagung di pasaran terus meningkat, oleh karena itu diperlukan berbagai upaya untuk meningkatkan produksi tanaman jagung di Sulawesi Tenggara. Beberapa kendala yang dihadapi untuk pengembangan jagung di Sulawesi Tenggara adalah ketersediaan lahan subur yang terbatas karena didominasi oleh jenis tanah Ultisol yang memiliki karakteristik kemasaman tanah tinggi, $\mathrm{pH}$ rata-rata $<4,50$, kejenuhan $\mathrm{Al}$ tinggi, miskin kandungan hara makro terutama $\mathrm{P}, \mathrm{K}, \mathrm{Ca}$, dan $\mathrm{Mg}$, dan kandungan bahan organik rendah (Prasetyo \& Suriadikarta, 2006).

Selain ketersediaan lahan subur yang terbatas, faktor lain yang mempengaruhi produktivitas tanaman jagung adalah adanya serangan penyakit tanaman seperti penyakit karat daun yang disebabkan oleh cendawan Puccinia polysora. Penyakit ini termasuk endemis dan sering menjadi penyebab utama rendahnya hasil jagung di beberapa daerah sentra produksi jagung di Indonesia (Sumartini, 1990). Penyebaran penyakit ini dilaporkan telah menyebar luas di wilayahwilayah sentra pertanaman jagung, terutama pada lokasi dengan kelembaban yang tinggi seperti di Sulawesi Tengah, Bali, Jawa Barat dan Jawa Tengah yang merupakan sentra produksi jagung (Pakki, 2016). Pada tingkat serangan berat, daun menjadi kering sehingga mematikan tanaman. Di Sulawesi Tenggara, informasi mengenai intensitas serangan penyakit ini belum dilaporkan, namun diduga penyakit ini sudah menyebar luas di beberapa sentra pertanaman jagung.

Teknik budidaya ramah lingkungan salah satunya dengan memadukan penggunaan bahan organik dan penggunaan agens hayati lokal merupakan langkah antisipatif yang bisa dilakukan. Pupuk Hayati Biofresh merupakan salah satu produk agens hayati lokal yang telah diketahui kemampuannya. Pupuk hayati Biofresh ini mengandung tiga isolat bakteri yaitu Bacillus subtilis ST21e, Bacillus cereus ST21b dan Serratia sp., SS29a yang memiliki beberapa kemampuan menghasilkan fitohormon IAA, melarutkan fosfat, dan memfiksasi $\mathrm{N}$ dari udara, serta mampu menghasilkan enzim-enzim pendegradasi seperti kitinase dan sellulase (Khaeruni, Sutariati, \& Wahyuni, 2010a). Lebih lanjut Khaeruni et al. (2018) melaporkan bahwa aplikasi pupuk hayati Biofresh yang dikombinasikan dengan bahan organik mampu menginduksi ketahanan tanaman kedelai terhadap penyakit pustul bakteri Xanthomonas axonopodis pv. glycine melalui peningkatan asam salisilat dan enzim peroksidase.Tujuan dari penelitian ini adalah mengevaluasi ketahanan tanaman jagung yang diberi pupuk hayati Biofresh dan pupuk organik Bokashi terhadap penyakit karat daun yang disebabkan oleh cendawan Puccinia polysora di lapangan.

\section{BAHAN DAN METODE}

\section{Bahan}

Bahan yang digunakan dalam penelitian ini adalah bahan organik bokashi jerami padi dan serasah kedelai, pupuk hayati Biofresh diproduksi oleh Laboratorium Proteksi Tanaman Fakultas Pertanian Universitas Halu Oleo; benih jagung BISI 2 diproduksi oleh PT. BISI Internasional Tbk. Kediri; kapur dolomit; dan pupuk anorganik Urea dengan dosis $200 \mathrm{~kg} \cdot \mathrm{ha}^{-1}$, SP36 200 kg.ha ${ }^{-1}$ dan KCl 85 kg.ha ${ }^{-1}$ diproduksi oleh PT. Petrokimia Gresik.

\section{Desain Penelitian}

Penelitian ini menggunakan Rancangan Acak Kelompok (RAK) Faktorial dimana faktor pertama adalah Aplikasi Pupuk Hayati Biofresh yang terdiri dari dua taraf yaitu A0 (Tanpa Pupuk Hayati Biofresh), A1 (Aplikasi Pupuk hayati Biofresh). Faktor Kedua adalah Dosis 
Bahan Organik yang terdiri atas empat taraf yaitu B1 (100\% Bahan Organik Bokashi), B2 (75\% Bahan Organik Bokashi), B3 (50\% Bahan Organik Bokashi), B4 (25\% Bahan Organik Bokashi), terdapat 8 kombinasi perlakuan yang diulangi sebanyak tiga kali sehingga terdapat 24 unit petak percobaan.

\section{Pengolahan Lahan dan Pembuatan Bedengan}

Pengolahan tanah dilakukan sebanyak 2 kali agar tanahnya menjadi lebih gembur, kemudian dibuat bedengan per plot perlakuan berukuran $3 \mathrm{~m} \times 2 \mathrm{~m}$, dengan tinggi $30 \mathrm{~cm}$, sebanyak 24 bedengan per plot perlakuan. Jarak antar bedengan perlakuan dalam kelompok $30 \mathrm{~cm}$, antar kelompok $40 \mathrm{~cm}$, serta jarak antara petak utama $50 \mathrm{~cm}$, sesuai dengan desain percobaan.

\section{Pengapuran dan Aplikasi Bahan Organik}

Pengapuran dilakukan pada semua bedengan per plot perlakuan menggunakan kapur dolomit $\left(\mathrm{CaMg}\left(\mathrm{CO}_{3}\right)_{2}\right)$, dilakukan 2 minggu sebelum tanam dosis 1,5 ton.ha ${ }^{-1}$. Aplikasi bahan organik dilakukan satu minggu sebelum tanam dengan cara ditabur merata di atas sesuai dengan dosis perlakuan. Kemudian bedengan dihaluskan dan diratakan.

\section{Penanaman Jagung dan Aplikasi Pupuk Hayati Biofresh}

Penanaman jagung dengan cara membuat lubang tanam sedalam $3 \mathrm{~cm}$ menggunakan tugal lalu dimasukan benih sebanyak 2 biji per lubang. Jarak tanam yang digunakan yaitu $30 \mathrm{~cm} \times 75 \mathrm{~cm}$. Aplikasi Pupuk Hayati Biofresh dilakukan pada bedengan per plot perlakuan sesuai dengan desain plot perlakuannya masing-masing sebanyak dua kali, aplikasi pertama dilakukan sesaat setelah menanam yang dijadikan sebagai penutup benih pada lubang tanaman dengan dosis $10 \mathrm{~g}$ per lubang, dan aplikasi kedua dilakukan pada umur tanaman 4 MST dengan cara ditaburkan disekitar pohon dan perakaran tanaman dengan dosis 24 g per rumpun, sehingga total dosis $34 \mathrm{~g}$ per rumpun tanaman atau setara dengan 1,5 ton.ha ${ }^{-1}$.

\section{Aplikasi Pupuk Anorganik Kimia Sintetis}

Pupuk anorganik kimia sintetis yang digunakan adalah pupuk urea, SP36 dan $\mathrm{KCl}$, dilakukan pada semua bedengan per plot perlakuan. Aplikasi pupuk SP36 dilakukan sesaat setelah menanam dengan cara ditugal sesuai dengan dosis perlakuan. Aplikasi pupuk urea dilakukan 2 kali yaitu pada umur 14 dan 35 HST, dan aplikasi pupuk $\mathrm{KCl}$ pada umur 14 HST Pemeliharaan tanaman.

\section{Analisis Ketahanan Tanaman}

Analisis aktivitas enzim peroksidase menggunakan metode Patra dan Mishra (1979). Penentuan aktivitas enzim peroksidase menggunakan Spektrofotometer UV-Vis, larutan campuran uji $(6 \mathrm{~mL})$ mengandung $1 \mathrm{~mL}$ buffer fosfat ( $\mathrm{pH} 6,5), 3 \mathrm{~mL}$ pyrogallol, $2 \mathrm{~mL} \mathrm{H}_{2} \mathrm{O}_{2} 1 \%$ dan $1 \mathrm{~mL}$ ekstraksi daun tanaman (hasil penggerusan sampel daun 1:10 g. $\mathrm{v}^{-1}$ ) Absorbansinya diukur pada panjang gelombang $420 \mathrm{~nm}$ jumlah purpurogalin terbentuk selama 5 menit.

\section{Parameter Pengamatan}

Parameter pengamatan dalam penelitian ini adalah: Intensitas Penyakit (IP) Karat daun Puccinia, Luas Daerah di Bawah Kurva Perkembangan Penyakit (LDBKPP), Indeks Penekanan Penyakit (IPP) dan Analisis Aktivitas Enzim Peroksidase.

\section{HASIL DAN PEMBAHASAN}

Berdasarkan hasil penelitian dan hasil analisis sidik ragam menunjukkan bahwa aplikasi pupuk hayati Biofresh mampu meningkatkan ketahanan tanaman dan menekan intensitas penyakit karat daun Puccinia dilapangan. Peningkatan ketahanan tanaman jagung terhadap penyakit karat daun Puccinia dibuktikan dari hasil analisis aktivitas enzim peroksidase, sedangkan kemampuan pupuk hayati Biofresh dalam menekan intensitas penyakit karat Puccinia ditunjukkan dari hasil analisis IP, LDBKPP, dan IPP.

\section{Intensitas Penyakit Karat Daun Puccinia}

Hasil analisis sidik ragam menunjukkan bahwa terdapat pengaruh interaksi antara pupuk hayati Biofresh dan bahan organik Bokashi. Perlakuan terbaik terbaik ditunjukkan pada perlakuan A1B1 dengan Intensitas Penyakit terendah yaitu sebesar 34,81\% pada 11 Minggu Setelah Tanaman (MST). Hal ini sangat berkaitan dengan komposisi dari pupuk hayati Biofresh yang terdiri tiga strain rizobakteri yaitu Bacillus subtilis ST21e, Bacillus cereus 21b dan Serratia sp. 
SS29a (Khaeruni et al., 2010a). Ketiga strain rizobakteri tersebut memiliki kemampuan menghasilkan fitohormon IAA, melarutkan fosfat, dan memfiksasi $\mathrm{N}$ dari udara, serta mampu menghasilkan enzim-enzim pendegradasi seperti kitinase, protease dan sellulase (Khaeruni, Sutariati, \& Wahyuni, 2010b).

Tabel 1. Pengaruh interaksi pupuk hayati Biofresh dan pupuk organik bokhasi jerami padi dan serasah kedelai terhadap intensitas penyakit karat daun Puccinia pada 9 MST, 10 MST dan 11 MST

\begin{tabular}{|c|c|c|c|c|c|c|}
\hline $\begin{array}{c}\text { Waktu } \\
\text { Pengamatan }\end{array}$ & Perlakuan & B1 & B2 & B3 & B4 & DMRT 0,05 \\
\hline \multirow{4}{*}{9 MST } & \multirow{2}{*}{ A0 } & $22,96 a$ & $22,96 a$ & $26,67 a$ & $31,85 a$ & \multirow{4}{*}{$\begin{array}{l}2=8,09 \\
3=8,46 \\
4=8,69\end{array}$} \\
\hline & & Q & Q & PQ & $\mathrm{P}$ & \\
\hline & \multirow{2}{*}{$\mathrm{A} 1$} & $17,04 \mathrm{a}$ & $18,51 a$ & $22,96 a$ & $20,74 b$ & \\
\hline & & P & P & P & P & \\
\hline \multirow{4}{*}{10 MST } & \multirow{2}{*}{ A0 } & $39,26 a$ & $42,22 a$ & $46,67 a$ & $54,81 a$ & \multirow{4}{*}{$\begin{array}{l}2=6,69 \\
3=6,99 \\
4=7,18\end{array}$} \\
\hline & & $\mathrm{R}$ & $\mathrm{QR}$ & Q & P & \\
\hline & \multirow{2}{*}{$\mathrm{A} 1$} & $28,15 b$ & $32,59 b$ & $34,07 b$ & $36,30 b$ & \\
\hline & & Q & $\mathrm{P}$ & $\mathrm{P}$ & $\mathrm{P}$ & \\
\hline \multirow{4}{*}{$11 \mathrm{MST}$} & An & $54,07 a$ & $58,52 a$ & $62,96 a$ & $71,85 a$ & \multirow{4}{*}{$\begin{array}{l}2=9,52 \\
3=9,96 \\
4=10,22\end{array}$} \\
\hline & AU & Q & Q & PQ & $\mathrm{P}$ & \\
\hline & \multirow{2}{*}{ A1 } & $34,81 b$ & $39,26 b$ & $38,15 b$ & $46,67 \mathrm{~b}$ & \\
\hline & & Q & $\mathrm{P}$ & $\mathrm{P}$ & $\mathrm{P}$ & \\
\hline \multicolumn{7}{|c|}{$\begin{array}{l}\text { Keterangan: Angka-angka yang diikuti oleh huruf yang sam } \\
\text { (kolom) pada perlakuan yang sama menunjuk } \\
\text { kepercayaan } 95 \%\end{array}$} \\
\hline Tabel 2. Nilai LDE & $P$ dan IPP pe & kit karat daur & Puccini & & & \\
\hline \multirow{2}{*}{ Perlakuan } & \multicolumn{5}{|c|}{ Nilai LDBKPP Penyakit Karat Daun Puccinia (\%.hari) } & \multirow{2}{*}{ IPP (\%) } \\
\hline & $49-56$ & $56-63$ & & $63-70$ & $70-77$ & \\
\hline A0B1 & 37,59 & 111,48 & & 217,78 & 326,67 & 32,35 \\
\hline A0B2 & 42,78 & 114,07 & & 228,15 & 352,59 & 27,68 \\
\hline A0B3 & 59,63 & 140,00 & & 256,67 & 383,70 & 13,23 \\
\hline A0B4 & 66,11 & 163,33 & & 303,33 & 443,33 & 0,00 \\
\hline A1B1 & 27,22 & 81,67 & & 158,15 & 220,37 & 51,74 \\
\hline A1B2 & 31,11 & 89,44 & & 178,89 & 251,48 & 45,62 \\
\hline A1B3 & 55,74 & 125,74 & & 199,63 & 252,78 & 28,97 \\
\hline A1B4 & 49,26 & 110,19 & & 199,63 & 290,37 & 31,68 \\
\hline
\end{tabular}

\section{LDBKPP dan IPP}

Hasil analisis LDBKPP penyakit karat daun Puccinia menunjukkan bahwa perlakuan A0B4 merupakan perlakuan dengan nilai LDBKPP tertinggi yaitu sebesar 443,33 \%.hari, sedangkan nilai LDBKPP terendah ditunjukkan pada perlakuan A1B1 pada periode $70-77$ hari setelah tanam yaitu sebesar 220,37 \%.hari. Semakin tinggi nilai LDBKPP maka perkembangan penyakit semakin tinggi pula dalam kurun waktu tertentu. Hal ini menunjukkan bahwa interaksi antara pupuk hayati Biofresh dan pupuk hayati memberikan pengaruh yang positif dalam menurunkan laju perkembangan penyakit karat daun Puccinia. Hal ini sejalan dengan nilai IPP dimana perlakuan A1B1 menunjukkan IPP tertinggi yaitu sebesar $51,74 \%$ jika dibandingkan dengan perlakuan lainnya. Kemampuan dalam menekan intensitas penyakit dan meningkatkan ketahanan tanaman terhadap intensitas penyakit karat daun Puccini diduga karena adanya interaksi antara komposisi pupuk hayati Biofresh dan bahan organik Bokashi. Bahan organik Bokashi yang terdiri dari jerami padi dan serasah kedelai selain memberikan efek positif terhadap 
pertumbuhan tanaman dengan memberikan unsur hara bagi tanaman juga memberikan efek yang positif pada mikroba penyusun pupuk hayati Biofresh. Bahan organik Bokashi akan meningkatkan kemampuan mikroba penyusun pupuk hayati Biofresh dalam menstimulasi pertumbuhan tanaman maupun ketahanan tanaman. Hal ini sejalan dengan penelitian yang dilakukan oleh Wijayanto, Khaeruni, Tufaila, Muhidin, dan Faat (2017) yang melaporkan bahwa kombinasi pupuk hayati Biofresh dan bahan organik mampu meningkatkan ketahanan tanaman kedelai terhadap penyakit pustul bakteri. Wijanarko, Purwanto, Shiddieq, dan Indradewa (2012) mengemukakan bahwa penambahan bahan organik ke dalam tanah akan meningkatkan aktivitas mikroorganisme perombak bahan organik. Serasah legum memiliki nisbah $\mathrm{C} / \mathrm{N}$ rasio yang lebih rendah jika dibandingkan dengan jenis bahan organik non legum yang memiliki $\mathrm{C} / \mathrm{N}$ rasio yang tinggi. Kandungan $\mathrm{C} / \mathrm{N}$ rasio mempengaruhi laju dekomposisi bahan organik oleh mikroba pendekomposer. Hal ini sejalan dengan pernyataan Isrun (2010) bahwa, tanaman legum baik digunakan sebagai bahan organik karena memiliki nisbah $\mathrm{C} / \mathrm{N}$ yang rendah jika dibandingkan dengan tanaman non legum dengan nisbah $\mathrm{C} / \mathrm{N}$ jauh lebih tinggi.

\section{Analisis Aktivitas Enzim Peroksidase}

Salah satu indikator ketahanan tanaman adalah adanya peningkatan aktivitas enzim peroksidase. Hasil penelitian menunjukkan bahwa aktivitas enzim peroksidase tertinggi

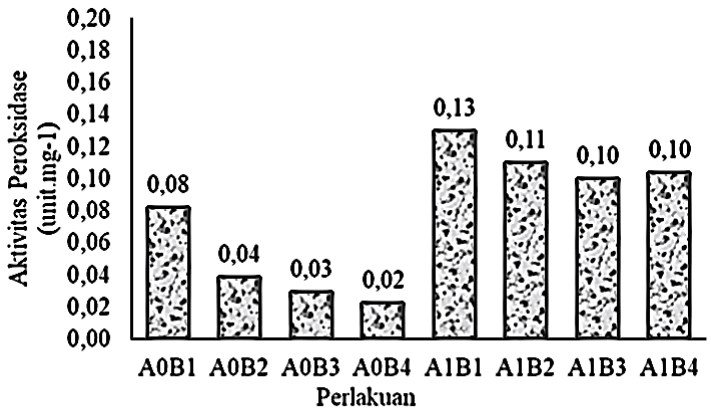

Gbr. 1. Aktivitas enzim peroksidase setelah aplikasi perlakuan pupuk hayati Biofresh dan pupuk organik bokashi

ditunjukkan pada perlakuan yang diaplikasikan pupuk hayati Biofresh yaitu perlakuan A1B1 dengan nilai aktivitas enzim peroksidase sebesar 0,13 unit.mg ${ }^{-1}$ (Gbr. 1). Peningkatan aktivitas enzim peroksidase ini sangat berkaitan aplikasi pupuk hayati Biofresh yang terdiri dari beberapa mikroba bermanfaat bagi tanaman yang telah diketahui kemampuannya dalam meningkatkan ketahanan tanaman diantaranya adalah Bacillus subtilis ST21e, Bacillus cereus 21b dan Serratia sp. SS29a (Khaeruni et al., 2010a). Hal ini sejalan dengan penelitian yang dilakukan oleh Yanti (2015) yang melaporkan pemberian rizobakteri isolat PK2Rp3 (Serratia marcescens strain N2.4) mampu meningkatkan aktivitas enzim peroksidase di akar dan di daun tanaman bawang merah. Aktivitas enzim peroksidase berkaitan dengan ketahanan tanaman yang berkaitan dengan lignifikasi pada jaringan tanaman. Terjadinya lignifikasi pada jaringan tanaman akan menghambat masuknya patogen selama proses infeksi pada tanaman. Hal ini sejalan dengan penelitian yang dilakukan oleh Silva et al. (2004) yang melaporkan bahwa aktivitas peroksidase dapat mencegah infeksi patogen karena lignifikasi yang menghambat masuknya patogen. Selain itu, peningkatan aktivitas peroksidase memiliki hubungan yang erat dengan laju perkembangan penyakit tanaman. Hal ini terlihat dari analisis regresi (Gbr. 2) yang menunjukkan bahwa semakin tinggi

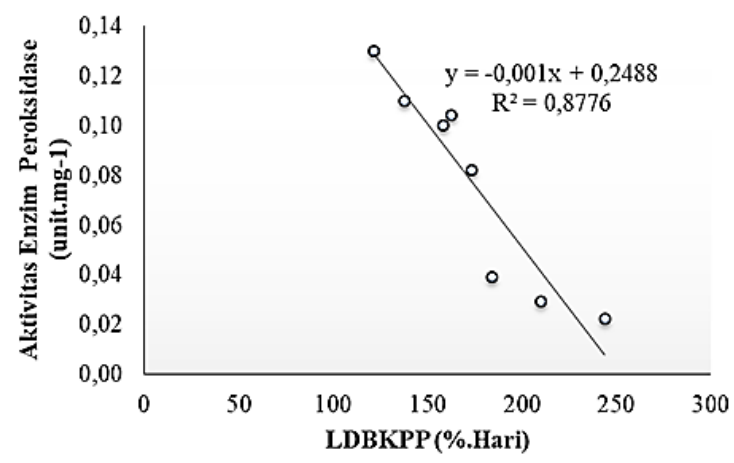
Gbr. 2. Hubungan antara aktivitas enzim peroksidase dengan IPP karat daun Puccinia

aktivitas peroksidase dalam jaringan tanaman nilai LDBKPP penyakit karat daun Puccinia semakin rendah, begitu pula sebaliknya. Hal ini menunjukkan bahwa aplikasi pupuk hayati Biofresh dan bahan organik Bokashi mampu meningkatkan ketahanan tanaman terhadap infeksi patogen yang kemudian mempengaruhi perkembangan penyakit tanaman di lapangan. 


\section{KESIMPULAN}

Aplikasi pupuk hayati Biofresh dan bahan organik Bokashi mampu meningkatkan ketahanan tanaman terhadap pengakit karat daun Puccinia pada tanaman jagung. Nilai LDBKPP terendah pada kombinasi perlakuan aplikasi pupuk hayati dan aplikasi bahan organik Bokashi 100\% (A1B1) sebesar 220,37\%.hari, IPP tertinggi pada perlakuan A1B1 sebesar $51,74 \%$ dan aktivitas enzim peroksidase tertinggi pada perlakuan A1B1 sebesar 0,13 unit. $\mathrm{mg}^{-1}$.

\section{DAFTAR PUSTAKA}

BPS. (2018). Statistik Indonesia. Jakarta: Badan Pusat Statistik R.I.

Isrun. (2010). Perubahan serapan nitrogen tanaman jagung dan kadar Al-dd akibat pemberian kompos tanaman legum dan nonlegum pada inseptisols napu. $J$. Agroland, 17(1), 23-29.

Khaeruni, A., Sutariati, G. A. K., \& Wahyuni, S. (2010a). Karakterisasi dan uji aktivitas bakteri rizosfer lahan ultisol sebagai pemacu pertumbuhan dan agensia hayati cendawan pathogen tular tanah secara in-vitro. Journal Hama dan Penyakit Tumbuhan Tropika, 10(2), 123-130.

Khaeruni, A., Sutariati, G. A. K., \& Wahyuni, S. (2010b). Potensi rizobakteria indigenus tanah podsolik merah kuning sebagai agens pengendali hayati penyakit layu Fusarium dan pemacu pertumbuhan tanaman mentimun. Jurnal Fitomedika, 7(1), 25-30.

Khaeruni, Johan, A. E. A., Wijayanto T., Taufik, M., Syafar, A. A. A. R., \& Sutariati, G. A. K. (2018). Induction of soybean resistance to bacterial pustule disease (Xanthomonas axonopodis $p v$. glycines) by rhizobacteria and organic material treatment. IOP Conf. Series: Earth and Environmental Science, 122, 012-052.

Pakki, S. (2016). Bionomi penyakit karat (Puccinia polysora) pada jagung dan pengendaliannya dengan varietas tahan dan fungisida. Prosiding Seminar Nasional Inovasi Teknologi Pertanian. Banjar Baru.
Patra, H. K., \& Mishra, D. (1979). Pyrophosphatase, peroxidase and polyphenoloxidase activities during leaf development and senescence. Plant Physiol, 63, 318-323.

Prasetyo, B. H., \& Suriadikarta, D. A. (2006). Karakteristik, potensi, dan teknologi pengelolaan tanah ultisol untuk pengembangan pertanian lahan kering di Indonesia. Jurnal Litbang Pertanian, 25(2), 39-46.

Silva, H. S. A., Romeiro, R. S., Macagnan, D., Halfeld-Vieira, B. A., Pereira, M. C. B., Mounteer, A. (2004). Induction of systemic resistance in tomato plants: nonspecific protection and increase in enzyme activities. Biologycal Control, 29(2), 288295.

Sumartini. (1990). Teknik Pelaksanaan Percobaan Tanaman Pangan. Malang: Balai Penelitian Tanaman Pangan (Balittan).

Wijanarko, A., Purwanto, B. H., Shiddieq, D., \& Indradewa, D. (2012). Pengaruh kualitas bahan organik dan kesuburan tanah terhadap mineralisasi nitrogen dan serapan $\mathrm{N}$ oleh tanaman ubikayu di Ultisol. J. Perkebunan \& Lahan Tropika, 2(2), 1-14.

Wijayanto, T., Khaeruni, A., Tufaila, M., Muhidin, \& Faat, D. (2017). The effectiveness of a biotechnological-based fertilizer "Biofresh" in combination with organic matters on soybean health and production. Research Journal of Pharmaceutical, Biological and Chemical Science, 8(2), 2808-2817.

Yanti, Y. (2015). Peroxidase enzyme activity of rhizobacteria-introduced shallots bulbs to induce resistance of shallot towards bacterial leaf blight (Xanthomonas axonopodis pv allii). Procedia Chemistry, 14, 501-507. 